\title{
Penerapan SAK ETAP Pada Koperasi Aktif di Jawa Barat Sebagai Acuan Pembuatan Aplikasi Akuntansi Koperasi Berbasis Android
}

\author{
Toufiq Agung Pratomo Sugito Putra \\ Muhamad Ardi Nupi Hasyim \\ Institut Manajemen Koperasi Indonesia \\ toufiq_agung@ikopin.ac.id \\ ardi@ikopin.ac.id
}

\begin{abstract}
ABSTRAK
Perkembangan teknologi informasi akuntansi sebenarnya telah berlangsung sejak lama. Hal ini dikarenakan penggunaan teknologi dalam akuntansi dapat menghemat waktu dan biaya serta penggunaan teknologi dalam akuntansi sangat dirasa efisien. Dalam rangka memberikan informasi akuntansi, maka dibuatlah sebuah sistem informasi yang dikenal dengan Sistem Informasi Akuntansi (SIA). Sistem informasi akuntansi yang baik membutuhkan perancangan sistem yang baik pula. pada Koperasi di Jawa Barat, pengolahan datanya masih dilakukan secara manual menggunakan Microsoft Excel yang menyebabkan koperasi ini rentan akan terjadinya kesalahan pencatatan. Selain kesalahan dalam pencatatan, keterlambatan penyampaian informasi juga dapat terjadi karena kurang efektifnya pencatatan. Oleh karena itu, pada koperasi ini perlu menggunakan sebuah sistem informasi akuntansi koperasi. Yang mana sistem ini nantinya dapat membantu pihak koperasi dalam melaksanakan proses transaksi yang ada pada koperasi tersebut secara efektif dan efisien serta terkomputerisasi dengan baik. Berdasarkan hal tersebut maka penelitian ini berjuan untuk mengetahui sistem informasi akuntansi pelaporan keuangan yang telah diterapkan oleh Koperasi dan merancang sistem informasi akuntansi pelaporan keuangan. Penelitian ini menggunakan metode kualitatif dan eksperimen, sedangkan metode perancangan aplikasi yang digunakan adalah waterfall. Metode pengembangan sistem yang dilakukan dalam penelitian ini adalah Netbeans IDE dengan bahsa pemograman Java dan Mysql sebagai penyimpanan databse serta iReport untuk mendesain laporan keuangan. Hasil yang didapatkan dari analisis dan perancangan yang dilakukan yaitu sebuah rancangan sistem informasi akuntansi yang mampu menunjang kebutuhan operasional Koperasi. Adapun keunggulan sistem yang dihasilkan yaitu adanya Bendahara yang secara khusus mengelola keuangan Koperasi sehingga proses pencatatan pelaporan keungan berjalan efektif dan efisien yang telah dirancang sesuai dengan kebutuhan Koperasi
\end{abstract}

Kata Kunci: Sistem Informasi Akuntansi, Koperasi;Aplikasi;SAKETAP;Jawa Barat

\begin{abstract}
The development of accounting information technology has actually been going on for a long time. This is because the use of technology in accounting can save time and costs and the use of technology in accounting is considered very efficient. In order to provide accounting information, an information system known as the Accounting Information System (SIA) was created. A good accounting information system requires a good system design too. At Cooperative, data processing is still done manually using Microsoft Excel, which makes this cooperative vulnerable to recording errors. Apart from errors in recording, delays in delivering information can also occur due to ineffective recording. Therefore, this cooperative needs to use a cooperative accounting information system. Which this system will later be able to assist the cooperative in carrying out the existing transaction process in the cooperative effectively and efficiently and well computerized. Based on this, this study aims to determine the financial reporting accounting information system that has been implemented by the Cooperative and to design an application-based savings and loan cooperative financial reporting accounting information system in accordance with the needs of Cooperative. This study used qualitative and experimental methods, while the application design method used was a waterfall. The system development method used in this research is Netbeans IDE with Java programming language and Mysql as database storage and iReport to design financial statements.The results obtained from the analysis and design carried out is an accounting information system design that is able to support the operational needs of Cooperative. The superiority of the resulting system is that there is a treasurer who specifically manages the finances of the Cooperative so that the process of recording financial reporting runs effectively and efficiently which has been designed according to the needs of Cooperative
\end{abstract}

Keyword : Accounting Information Systems, Cooperatives,Aplication;SAKETAP;WestJava 


\section{PENDAHULUAN}

Perkembangan ekonomi Indonesia yang sedang berkembang pesat saat ini merupakan wujud dari tujuan nasional. Tujuan Nasional ini tercantum dalam Undang-Undang Dasar (UUD) 1945 yang tertuang pada pasal 33 ayat 1 yang menyatakan bahawa "perekonomian disusun sebagai usaha bersama berdasarkan atas asas kekeluargaan". Dalam penjelasan Undang-Undang Dasar 1945 disebutkan bahwa usaha yang sesuai dengan pasal tersebut adalah koperasi. (Mulyani, 2013). UndangUndang Nomor 25 tahun 1992 tentang Perkoperasian ayat 2 menjelaskan bahwa Koperasi berlandaskan Pancasila dan Undang-Undang Dasar 1945 berdasar atas asas kekeluargaan. Koperasi terdapat hampir disemua negara. Pada mulanya koperasi tumbuh dinegara eropa Barat, namun setelah adanya kolonialisme di beberapa negara di Asia, Afrika, dan Amerika Selatan koperasi juga tumbuh dinegara jajahan. Banyak negara yang memanfaatkan koperasi sebagai alat pemerintah dalam melaksanakan pembangunan (Heriyono, 2012).

Salah satu peran Koperasi yang paling krusial dalam pertumbuhan ekonomi adalah menstimulus dinamisasi ekonomi. Karakternya yang fleksibel dan cakap membuat Koperasi dapat direkayasa untuk mengganti lingkungan bisnis yang lebih baik daripada perusahaan-perusahaan besar, karena Koperasi dan UKM dianggap mampu beradaptasi dengan pasang surut dan arah permintaan pasar.(Siagian, dkk, 2016) Sebagai sebuah lembaga ekonomi yang nantinya akan menghasilkan sebuah laporan keuangan, koperasi sudah dipastikan akan berhubungan dengan berbagai pihak yang memiliki kepentingan terhadap hasil kinerja mereka (Khalid, 2012). Menurut Ikatan Akuntan Indonesia (IAI) (2009:2) tujuan laporan keuangan adalah menyediakan informasi posisi keuangan, kinerja keuangan, dan laporan arus kas suatu entitas yang bermanfaat bagi sejumlah besar pengguna dalam pengambilan keputusan ekonomi oleh siapapun yang tidak dalam posisi dapat meminta laporan keuangan khusus untuk memenuhi kebutuhan informasi tertentu. Pengurus koperasi yang mengelola koperasi harus melaporkan kegiatan selama satu tahun kepada anggota pada saat Rapat Anggota Tahunan (RAT) sebagai bentuk pertanggungjawaban pengurus koperasi kepada anggota.

Penerapan akuntansi dan penyampaian laporan keuangan koperasi memiliki kekhususan tersendiri dibandingkan dengan penerapan akuntansi dan laporan keuangan usaha yang lain. Laporan keuangan koperasi berpedoman pada Standar Akuntansi Keuangan Entitas Tanpa Akuntabilitas (SAK ETAP) yang mengacu pada The International Financial Reporting Standard for Small and
Medium - Sized Entitas (IFRS for SMEs). SAK ETAP ditetapkan oleh Ikatan Akuntan Indonesia sebagai pedoman dalam menyusun laporan keuangan sebagai pengganti PSAK No. 27 tentang perkoperasian yang tidak berlaku lagi.

Berubahnya standar penyusunan laporan keuangan, maka entitas (koperasi) harus memiliki komitmen yang tinggi untuk mencapai laporan keuangan yang handal dan relevan sesuai dengan SAK ETAP. Dijelaskan dalam penelitian Eni dan Krisan (2014) setiap koperasi diharuskan melakukan pembenahan baik dalam sumber daya manusia, komitmen dari setiap pegawai maupun perangkat pendukung seperti teknologi informasi dan komunikasi. Hasil penelitian Yuliza dan Afrijal (2016:101) tentang analisis penerapan SAK ETAP pada koperasi Universitas Pasir Pengaraian (UPP) dijelaskan bahwa koperasi UPP belum memahami akuntansi koperasi hal ini disebabkan tidak sesuainya latar belakang pendidikan dan kurangnya pelatihan yang menyebabkan terkendalanya proses pelaporan keuangan koperasi UPP. Selanjutnya, dijelaskan oleh Hevesi (2005) kompetensi merupakan karakteristik dari seseorang yang memiliki keterampilan (skill), pengetahuan (knowledge), dan kemampuan (ability). Wicaksono (2016) menjelaskan keikutsertaan para pelaku usaha dalam program pembinaan atau pelatihan mengenai SAK ETAP sangat mempengaruhi persepsi pelaku usaha akan pentingnya pelaporan keuangan yang sesuai dengan SAK ETAP

Menurut Warno (2014) penyebab koperasi di Indonesia banyak hambatan dikarenakan pertama, terbatasnya pengetahuan manajemen yang mengakibatkan kesulitan untuk menganalisis usaha, kedua ketidak mampuan dalam mengidentifikasi peluang-peluang usaha, ketiga rendahnya pendidikan dan pengalaman dalam bidang akuntansi menjadi kendala yang harus dihadapi oleh koperasi. Yuliza dan Afrijal (2016) faktor tidak sesuainya latar belakang pendidikan dan kurangnya pelatihan juga menyebabkan proses pelaporan keuangan pada koperasi UPP juga menjadi kendala. Selain itu, dalam penelitian Novia dan Sulastingsih (2018) dijelaskan kurangnya sosialisasi penerapan SAK ETAP dari pihak-pihak yang bersangkutan seperti Dinas Koperasi dan UKM sehingga pelaku usaha tidak mengetahui standar laporan keuangan.

Koperasi merupakan soko guru perekonomian nasional, menurut Rudianto (2010) koperasi merupakan sebuah kelompok atau perkumpulan orang-orang yang dengan sukarela bersatu memperjuangkan peningkatan kesejahteraan ekonomi mereka dengan membuat sebuah badan usaha yang dikelola secara demokratis. Namun, dalam masa kini keberadaan koperasi dinilai ketinggalan zaman, hal itu dikarenakan tidak adanya perubahan dalam pengelolaan koperasi 
dimana koperasi hanya berfokus pada kegiatan usahanya tanpa didukung oleh sumber daya manusia yang kuat serta yang paling penting di era modern ini adalah kemajuan teknologi informasi (Wardana dkk.,2018). Seiring dengan berjalannya waktu, koperasi pun harus menyesuaikan diri dengan berbagai perkembangan dunia dimasa sekarang. Dunia saat ini telah memasuki Revolusi Industri 4.0, dimana perkembangan teknologi semakin canggih dan berbagai informasi serta pertukaran data pun semakin cepat. Kecepatan informasi yang diterima pada hakikatnya harus tepat dan akurat. Salah satu teknologi yang berkembang pesat adalah perkembangan teknologi informasi akuntansi.

Perkembangan teknologi informasi akuntansi sebenarnya telah berlangsung sejak lama. Hal ini dikarenakan penggunaan teknologi dalam akuntansi dapat menghemat waktu dan biaya serta penggunaan teknologi dalam akuntansi sangat dirasa efisien. Selain itu, perkembangan penggunaan teknologi informasi dalam bidang akuntansi dipicu karena adanya peningkatan efektifitas demi menghasilkan output keuangan yang tepat dan akurat. Dalam tatanan perusahaan atau organisasi, tugas serta fungsi akuntansi berada pada tingkatan transaksional dan operasional. Tingkatan ini punya karakteristik pekerjaan teknis, repetitif, prosedural, standar dan juga dapat membuat bosan. Karakteristik inilah yang membuat kebutuhan teknologi informasi diperlukan dalam perkembangan bidang akuntansi (Akuntansi Online, 2016). Dari penjelasan diatas dapat disimpulkan betapa pentingnya fungsi akuntansi dalam tatanan perusahaan.

Dari pengamatan dan informasi yang diperoleh pada Koperasi di Jawa barat, pengolahan datanya masih dilakukan secara manual menggunakan Microsoft Excel yang menyebabkan koperasi ini rentan akan terjadinya kesalahan pencatatan. Selain kesalahan dalam pencatatan, keterlambatan penyampaian informasi juga dapat terjadi karena kurang efektifnya pencatatan. Oleh karena itu, pada koperasi ini perlu menggunakan sebuah sistem informasi akuntansi koperasi. Yang mana sistem ini nantinya dapat membantu pihak koperasi dalam melaksanakan proses transaksi yang ada pada koperasi tersebut secara efektif dan efisien serta terkomputerisasi dengan baik. Seperti pada penelitian yang dilakukan oleh Lestari (2017) dimana penulis membuat perancangan sistem informasi akuntansi penggajian untuk membantu pengolahan transaksi dan pembuatan laporan keuangan pada KSP Borromeus menjadi terkomputerisasi dengan baik.

\section{METODE PENELITIAN}

Uji coba aplikasi di lakukan pada Koperasi Koperasi Wanita Aisyiyah Kiprah Khadijah Kabupaten Garut Jawa Barat. Metode perancangan aplikasi yang digunakan adalah waterfall. Pressman (dalam Sasmito, 2017) menjelaskan bahwa metode waterfall merupakan model pengembangan sistem informasi yang sistematik dan sekuensial. Menurut Sommerville (dalam Ginanjar, 2017) metode Waterfall memiliki tahapan-tahapan sebagai berikut:

\section{Requirements analysis and definition}

Layanan sistem, kendala, dan tujuan ditetapkan oleh hasil konsultasi dengan pengguna yang kemudian didefinisikan secara rinci dan berfungsi sebagai spesifikasi sistem.

\section{System and software design}

Tahapan perancangan sistem mengalokasikan kebutuhan-kebutuhan sistem baik perangkat keras maupun perangkat lunak dengan membentuk arsitektur sistem secara keseluruhan. Perancangan perangkat lunak melibatkan identifikasi dan penggambaran abstraksi sistem dasar perangkat lunak dan hubungannya.

\section{Implementation and unit testing}

Pada tahap ini, perancangan perangkat lunak direalisasikan sebagai serangkaian program atau unit program. Pengujian melibatkan verifikasi bahwa setiap unit memenuhi spesifikasinya.

\section{Integration and system testing}

Unit-unit individu program atau program digabung dan diuji sebagai sebuah sistem lengkap untuk memastikan apakah sesuai dengan kebutuhan perangkat lunak atau tidak. Setelah pengujian, perangkat lunak dapat dikirimkan ke customer

\section{Operation and maintenance}

Biasanya (walaupun tidak selalu), tahapan ini merupakan tahapan yang paling panjang. Sistem dipasang dan digunakan secara nyata. Maintenance melibatkan pembetulan kesalahan yang tidak ditemukan pada tahapan-tahapan sebelumnya, meningkatkan implementasi dari unit sistem, dan meningkatkan layanan sistem sebagai kebutuhan baru. 


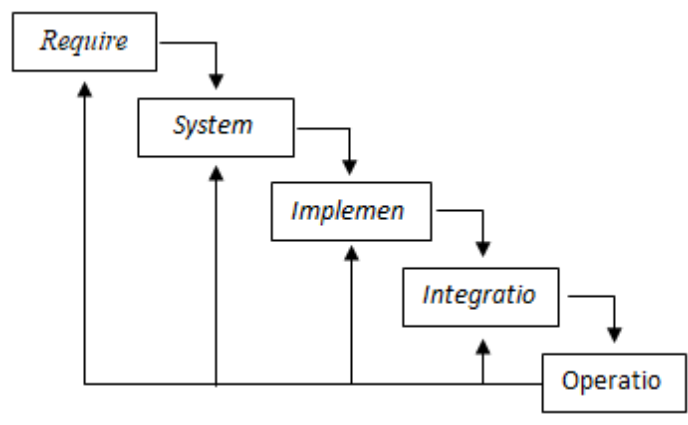

\section{Gambar 1 Metode Waterfall}

Analisis sistem yang sedang berjalan atau diterapkan bertujuan untuk menganalisis sistem yang ada secara rinci dan detail terhadap permasalahan yang berjalan sebagai dasar untuk pengusulan perancangan sistem. Berdasarkan wawancara dan survey yang dilakukan peneliti, kegiatan pencatatan keuangan dari mulai transaksi hingga pelaporan keuangan pada Koperasi Simpan Pinjam Wanita 'Aisyiyah Kiprah Khadijah Kabupaten Garut masih dilakukan secara manual menggunakan aplikasi program Microsoft Excel sebagai alat bantu pengelolaan data keuangan. Penggunaan aplikasi program Microsoft Excel akan rentan dengan resiko keamanan dan keselamatan data. Salah satu keamanan data yang dimaksud adalah data tetap terjaga dan dapat diatasi ketika terjadi kerusakan yang diakibatkan oleh kelalaian pengguna maupun yang diakibatkan oleh komputer itu sendiri, maka dibutuhkan suatu sistem informasi akuntansi berbasis android yang dapat mengatasi permasalahan yang ada pada Koperasi Simpan Pinjam Wanita 'Aisyiyah Kiprah Khadijah Kabupaten Garut. Dimana aplikasi yang dibutuhkan akan membantu pengelolaan data keuangan yang dilakukan semakin efektif dan efisien.

\section{HASIL DAN PEMBAHASAN}

Dewan Standar Akuntansi Keuangan (DSAK) dan Ikatan Akuntan Indonesia (IAI)dibawah Kementerian Keuangan pada tanggal 8 April 2011 telah mencabut Pernyataan Standar Akuntansi Keuangan 27 (PSAK 27) tentang Akuntansi Koperasi. Dengan dicabutnya PSAK 27, DSAK dan IAI menerbitkan Standar Akuntansi Keuangan entitas Tanpa Akuntabilitas Publik (SAK ETAP). Pada dasarnya SAK ETAP mengacu pada International Financial Reporting Standard for Small and Medium-Sized Entitas(IFRS for SMEs).Menurut Wuwungan (2015) menyatakan bahwa standar akuntansi keuangan (SAK) adalah suatu kerangka dalam prosedur pembuatan laporan keuangan agar terjadi suatu keseragaman dalam penyajian laporan keuangan. Dalam penelitian Renaldy, dkk (2016) diejelaskan SAK ETAP akan dinyatakan efektif jika memiliki 2 kriteria yakni tidak memiliki akuntabilitas publik secara signifikan dan tidak menerbitkan laporan keuangan untuk tujuan umum bagi pengguna eksternal. Kriteria ETAP tersebut, bisa dibedakan dengan entitas yang memiliki akuntabilitas publik, yaitu jika Entitas telah mengajukan pernyataan pendaftaran atau entitas dalam proses pengajuan pernyataan pendaftaran pada otoritas pasar modal (BAPEPAM-LK) atau regulator lain untuk tujuan penerbitan efek di pasar modal; Entitas mengusai aset dalam kapasitas sebagai fidusia untuk kelompok besar masyarakat, seperti bank, entitas asuransi, pialang dan /atau pedagang efek, dana pensiun, reksa dana, dan bank investasi.

Pengukuran adalah proses penetapan jumlah uanmg yang digunakan entitas untuk mengukur aset, kewajiban, penghasilan, dan beban dalam laporan keuangan. Dasar pengukuran yang umum adalah biaya hsitoris dan nilai wajar.Entiitas harus mernyusun laporan keuangan, dengan menggunakan dasar akrual, kecuali laporan arus kas. Dalam dasar akrual, pos-pos diakui sebagai aset, kewajiban, ekuitas, penghasilan, dan beban (unsur-unsur laporan keuangan) jika memenuhi definisi dan kriteria pengakuan untuk pos-pos tersebut.

Penyajian dan klasifikasi pos-pos dalam laporan keuangan harus tetap sama (konsisten) dari periodeke periode berikutnya. Perubahan di dalam penyajian hanya diperbolehkan bilamana Standar mengharuskan perubahan dalam penyajian, Terjadi perubahan yang signifikan dalam sifat operasi dari entitas, atau suatu kajian terhadap laporan keuangannya yang mengharuskan penggunaan penyajian, atau klasifikasi lainnya yang dianggap lebih memadai. Penerapan akuntansinya mengacu kepada SAK ETAP. Bentuk laporan keuangan yang sekurang-kurangnya diterbitkan sebanyak 1 (satu) bulan yang berupa Neraca, Perhitungan Hasil Usaha, Laporan Arus Kas, Laporan Perubahan Ekuitas, Catatan Atas Laporan Keuangan

Berdasarkan permasalahan yang telah dijelaskan, bahwa pengelolaan data keuangan yang dilakukan oleh Koperasi Simpan Pinjam Wanita 'Aisyiyah Kiprah Khadijah belum dilakukan secara efektif dan efisien karena belum menggunakan aplikasi keuangan yang optimal sehingga terjadi permasalahan hilangnya data, dan kekurangankekurangan lain seperti pada proses pengelolaan data dan penyebaran informasi. Adapun sistem yang sedang berjalan adalah: 


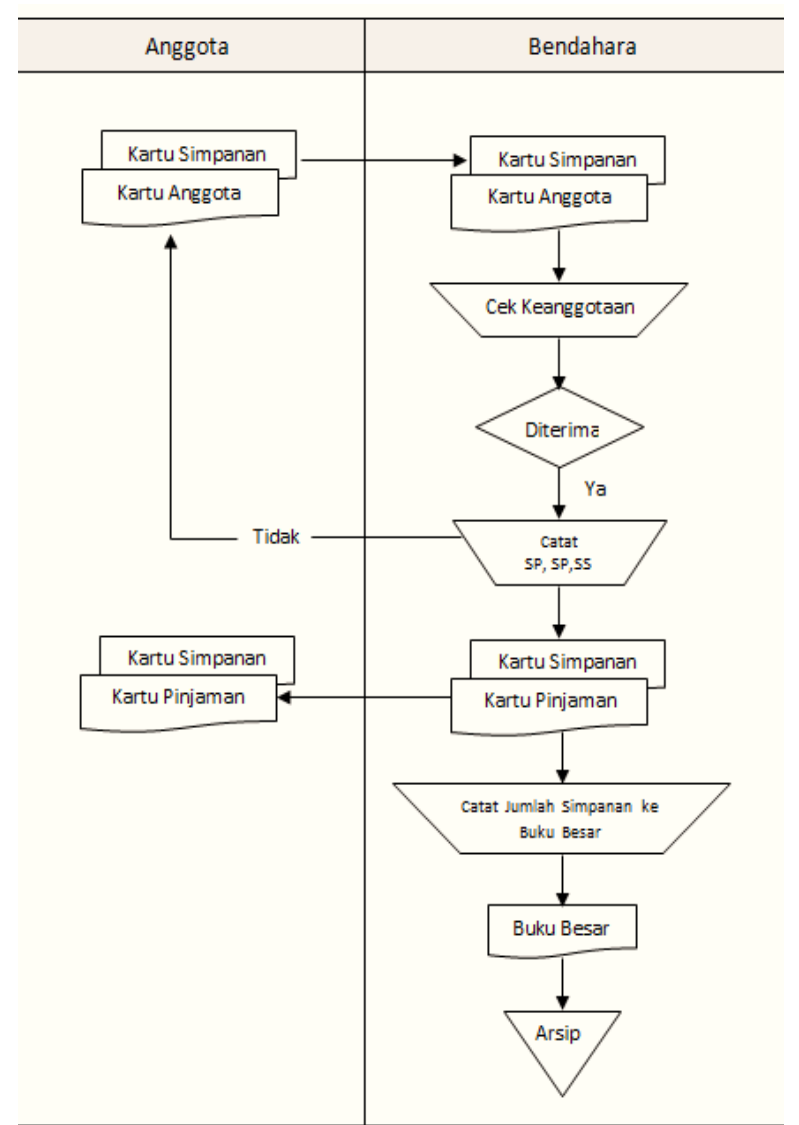

Gambar 2 Flowmap Pinjaman yang digunakan

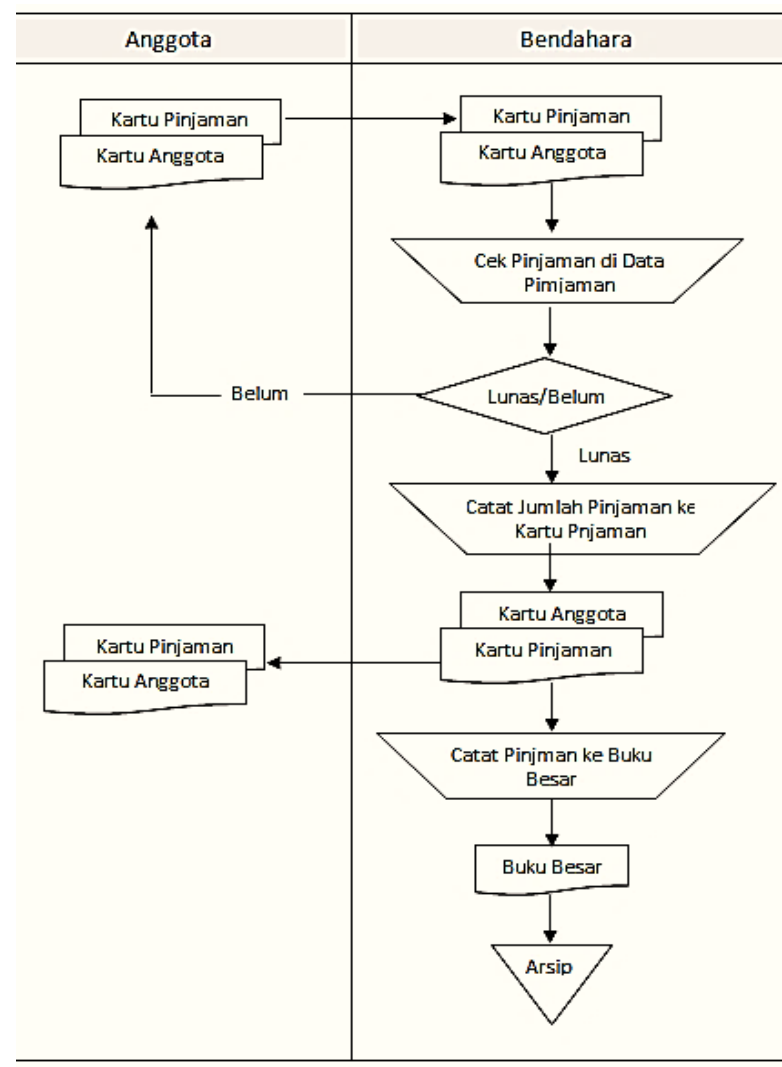

Gambar 3 Flowmap Pinjaman yang sedang Berjalan

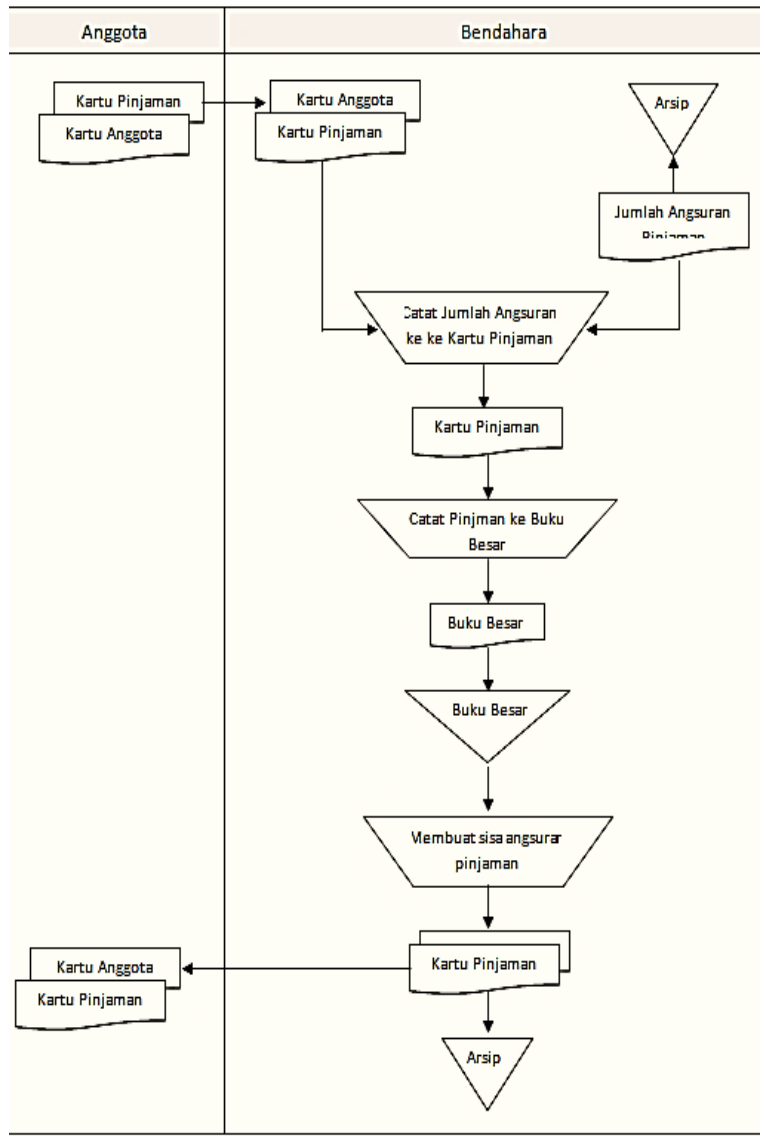

\section{Gambar 4 Flowmap Angsuran yang sedang Berjalan}

Analisis Masalah pada Sistem yang Diterapkan

Analisis masalah dilakukan untuk mengetahui permasalahan apa saja yang yang terjadi pada sistem yang sedang berjalan. Analisis masalah yang dimaksud adalah ditemukan adanya tahapan manual yang harus dikerjakan, keamanan data salah satu yang terjadi yaitu hilangnya data laporan keuangan dikarenakan kerusakan hardisk dan sistem tidak dapat melakukan backup data otomatis, serta format sistem yang tidak permanen (dalam hal ini kelalain pengguna dapat mengakibatkan terjadinya perubahan pada format yang telah dirancang dan hasil pengolahan data menjadi tidak akurat). Hal ini mengakibatkan tidak efektif dan efisiennya pengolahan data yang dilakukan oleh Koperasi Simpan Pinjam Wanita 'Aisyiyah Kiprah Khadijah Kabupaten Garut. Maka dari itu diperlukan sistem yang dapat mengatasi masalah-masalah tersebut dengan dirancang sistem baru sesuai dengan kebutuhan Koperasi Wanita 'Aisyiyah Kiprah Khajidah Kabupaten Garut agar pengolahan data dapat berjalan dengan efektif dan efisien, dan dengan adanya sisem atau aplikasi yang baru diharapkan dapat membantu kinerja dari pihak koperasi yang menjalankan tugasnya. 


\section{Analisis Kebutuhan Sistem}

Berdasarkan hasil wawancara dan observasi yang dilakukan, maka aplikasi yang dibuat adalah aplikasi akuntansi berbasis android. Alat pemograman yang digunakan adalah Netbeans IDE dengan bahsa pemograman Java dan Mysql sebagai penyimpanan databse serta iReport untuk mendesain laporan keuangan.

a. Kebutuhan Data

1) Data Anggota Koperasi Wanita 'Aisyiyah Kiprah Khadijah Garut

2) Data Simpanan Anggota Koperasi Wanita 'Aisyiyah Kiprah Khadijah Garut

3) Data Pinjaman Anggota Koperasi Wanita 'Aisyiyah Kiprah Khadijah Garut

4) Data Akun Transaksi Koperasi Wanita 'Aisyiyah Kiprah Khadijah Garut

5) Data SHU Anggota Koperasi Wanita 'Aisyiyah Kiprah Khadijah Garut

b. Kebutuhan Fungsional

Penjelasan proses fungsi adalah suatu bagian yang berupa penjelasan secara terperinci setiap fungsi untuk menyelesaikan masalah. Fungsifungsi yang dimiliki oleh perancangan sistem aplikasi dekstop ini adalah :

1) Memiliki menu login yang harus diisi username dan password yang dimiliki oleh bendahara.

2) Memiliki menu anggota.

3) Menu transaksi anggota dengan submenu data simpanan dan pinjaman.

4) Menu buku harian dengan submenu pengeluaran kas dan penerimaan kas

5) Menu pembukuan dengan submenu data akun, jurnal penyesuaian, neraca saldo, dan buku besar.

6) Menu laporan dengan submenu sisa hasil usaha, neraca, perubahan ekuitas, dan arus kas.

\section{Perancangan Sistem Informasi Akuntansi} Pelaporan Keuangan Koperasi Simpan Pinjam

Flowmap Sistem yang diusulkan

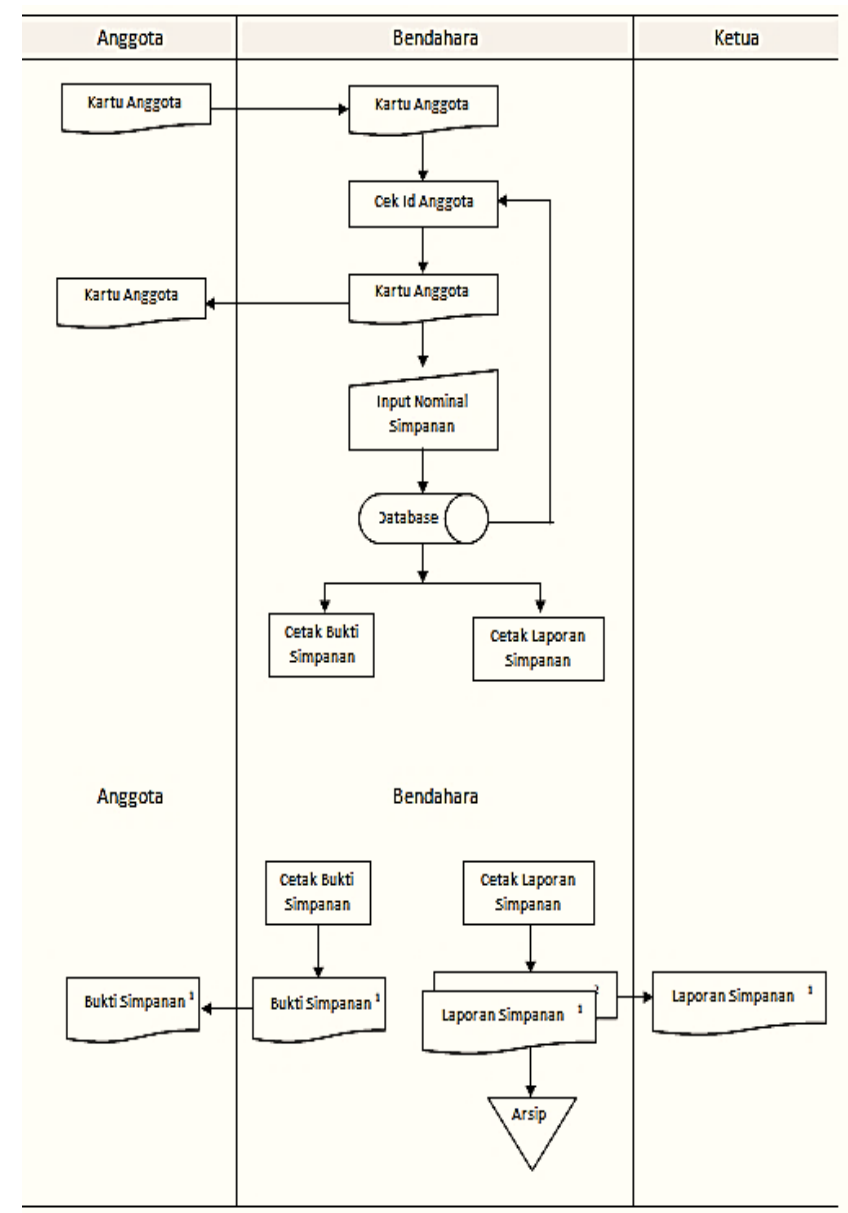

Gambar 5 Flowmap Simpanan yang diusulkan 


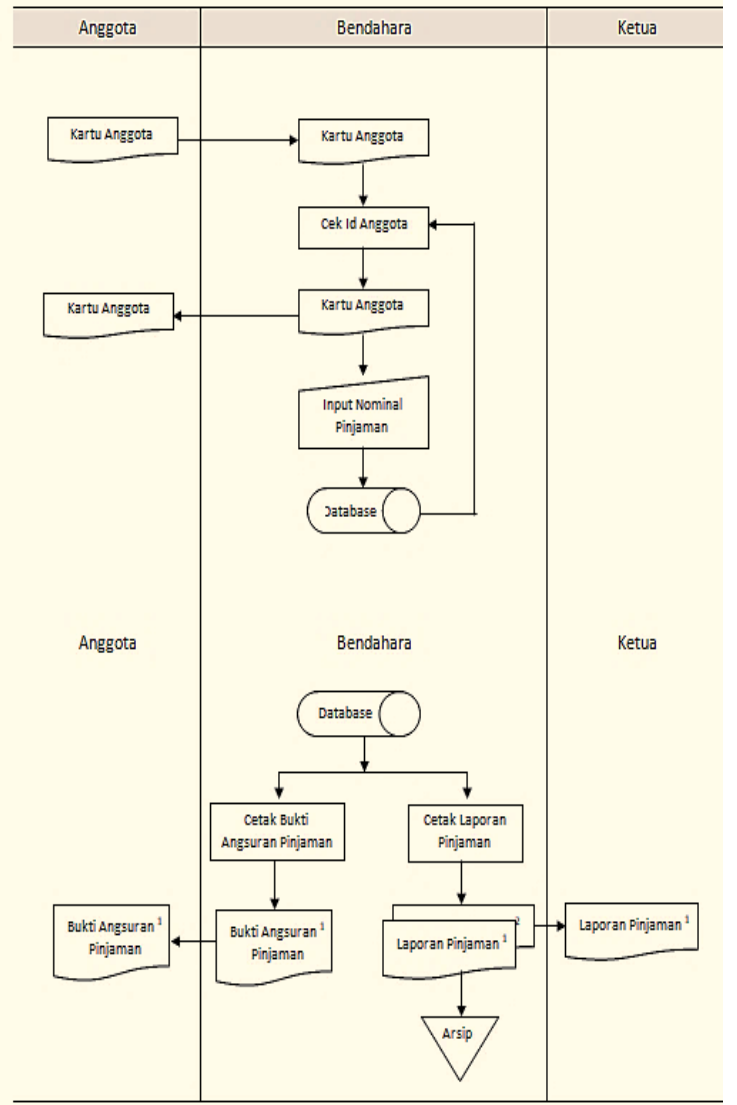

Gambar 6 Flowmap Pinjaman yang diusulkan

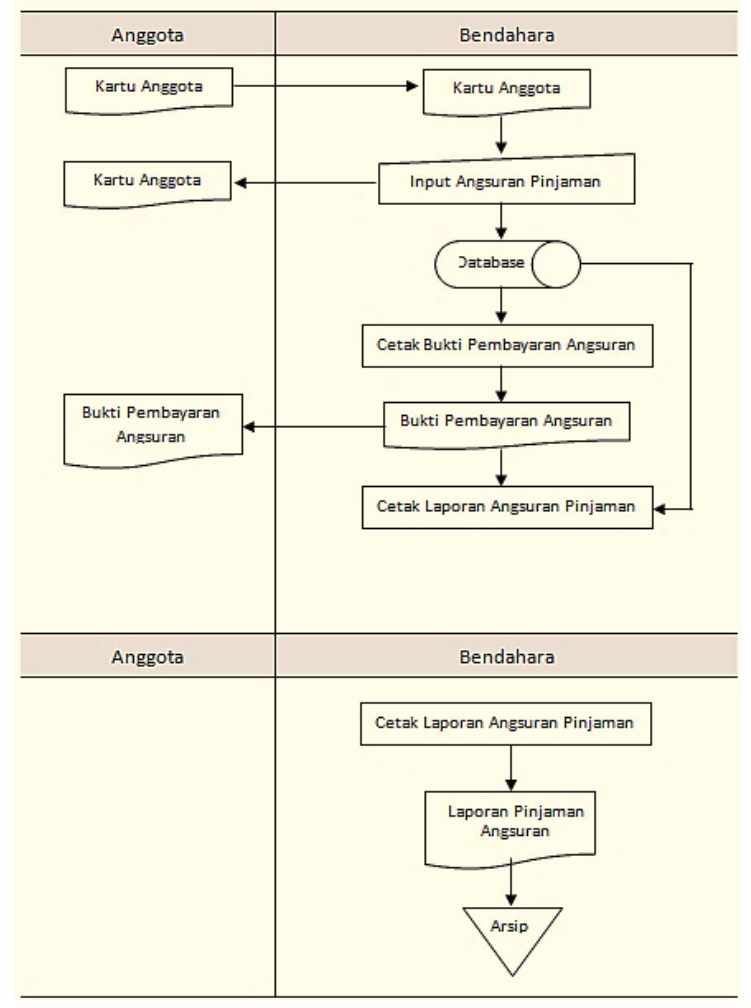

Gambar 7 Flowmap Angsuran yang diusulkan
Perancangan Sistem

a. Data Flow Diagram Konteks Level 0

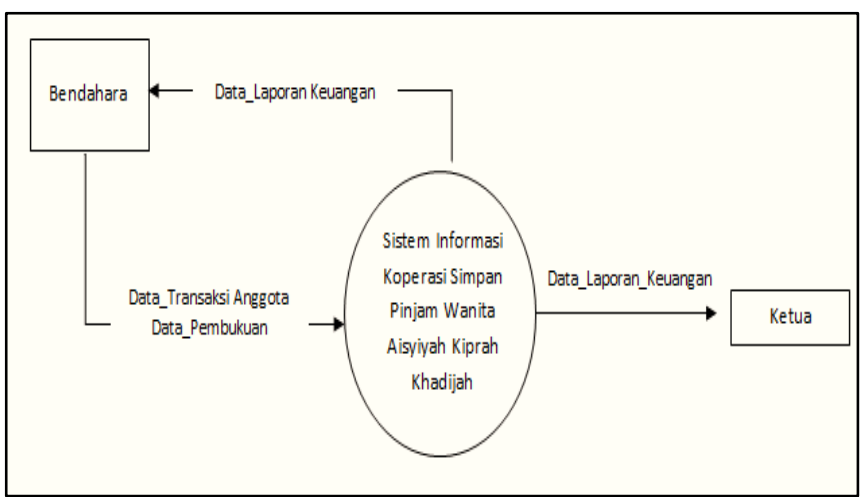

Gambar 8 Diagram Konteks

b. Data Flow Diagram Level 1

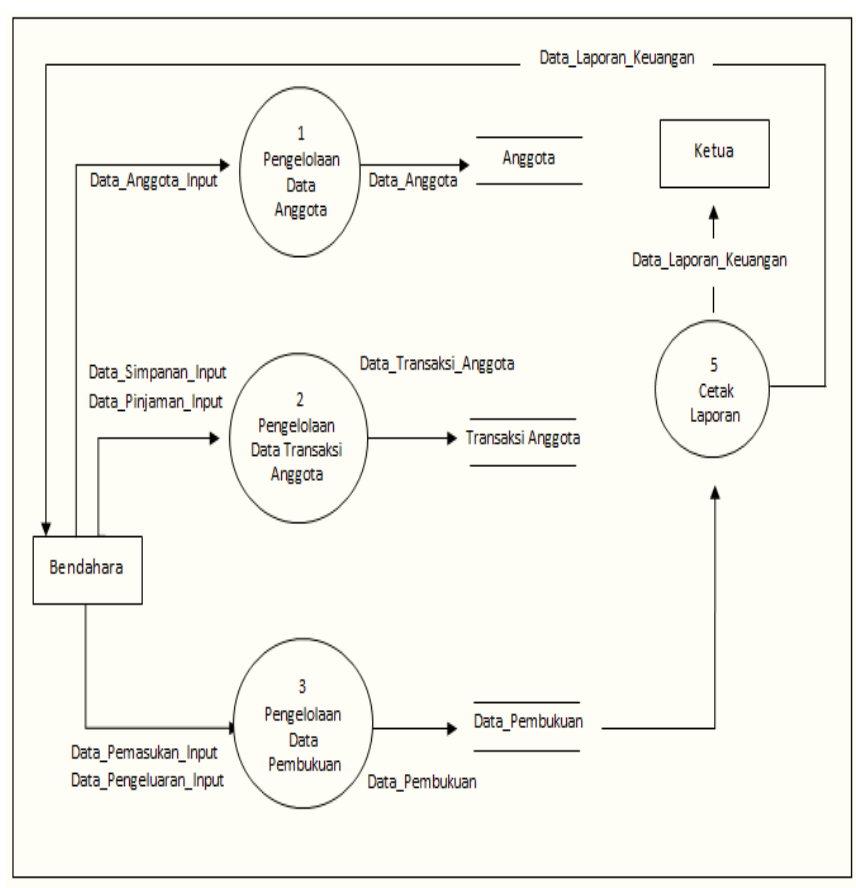

\section{Gambar 9 Data Flow Diagram Level 1}

\section{Perancangan Database}

Pembuatan database pada penelitian ini menggunakan bahasa Mysql. Selain penggunaan databse, peneliti juga menghubungkan database yang terkait agar dapat saling menyingkronkan tabel-tabel di dalamnya. Berikut adalah tabel-tabel di dalam perancangan sistem aplikasi ini. 
1. Tabel Anggota

Nama Tabel : t_anggota

Primary Key: no_anggota

Fungsi : menginput data anggota

Tabel 1 Anggota

\begin{tabular}{lccc}
\hline Field Name & Type & Width & Keterangan \\
\hline no_anggota & Varchar & 11 & Primary key \\
nama & Varchar & 30 & \\
Alamat & Varchar & 50 & \\
sim_pokok & Varchar & 20 & \\
no_tlp & Varchar & 20 & \\
pekerjaan & Varchar & 30 & \\
tgl_masuk & Date & & \\
\hline
\end{tabular}

2. Tabel Pekerjaan

Nama Tabel : t_pekerjaan

Primary Key : no_pek

Fungsi : menginput data pekerjaan

Tabel 2 Pekerjaan

\begin{tabular}{lccc}
\hline Field Name & Type & Width & Keterangan \\
\hline no_pek & Varchar & 5 & Primary key \\
pekerjaan & Varchar & 20 & \\
\hline
\end{tabular}

3. Tabel Akun

Nama Tabel : t_akun

Primary Key : kode_akun

Fungsi : menginput data akun

Tabel 3 Akun

\begin{tabular}{lccc}
\hline \multicolumn{1}{c}{ Field Name } & Type & Width & Keterangan \\
\hline kode_akun & Int & 10 & Primary key \\
nama_akun & Varchar & 10 & \\
tipe & Varchar & 10 & \\
id_jurnal_umum & Int & 3 & Foreign key \\
\hline
\end{tabular}

4. Tabel Periode

Nama Tabel : t_periode

Primary Key : kode_periode

Fungsi : menginput data periode

Tabel 4 Periode

\begin{tabular}{cccc}
\hline Field Name & Type & Width & Keterangan \\
\hline kode_periode & Int & 3 & Primary key \\
nama_periode & Varchar & 10 & \\
\hline
\end{tabular}

5. Tabel Simpanan

Nama Tabel : t_simpan

Primary Key : kd_simpanan

Fungsi : menginput data simpanan
Tabel 5 Simpanan

\begin{tabular}{lccc}
\hline \multicolumn{1}{c}{ Field Name } & Type & Width & Keterangan \\
\hline kd_simpanan & Varchar & 10 & Primary key \\
no_anggota & Varchar & 20 & \\
nama & Varchar & 30 & \\
tgl_simpanan & Data & & \\
setoran & Int & 20 & \\
saldo & Varchar & 20 & \\
tot_saldo & Varchar & 20 & \\
\hline
\end{tabular}

6. Tabel Pinjaman

$$
\begin{array}{ll}
\text { Nama Tabel } & : \text { t_pinjam } \\
\text { Primary Key } & : \text { kd_pinjaman } \\
\text { Fungsi } & : \text { menginput data pinjaman }
\end{array}
$$

Tabel 6 Pinjaman

\begin{tabular}{lccc}
\hline \multicolumn{1}{c}{ Field Name } & Type & Width & Keterangan \\
\hline kd_pinjaman & Varchar & 10 & Primary key \\
no_anggota & Varchar & 20 & \\
nama & Varchar & 20 & \\
jml_pinjam & Varchar & 20 & \\
tgl_pinjam & Date & & \\
tgl_tempo & Date & & \\
lama & Varchar & 5 & \\
bunga & Varchar & 5 & \\
jml_bunga & Int & 20 & \\
tot_pinjaman & Varchar & 20 & \\
angsuran & Varchar & 20 & \\
\hline
\end{tabular}

7. Tabel Angsuran

$$
\begin{array}{ll}
\text { Nama Tabel } & : \text { t_angsuran } \\
\text { Primary Key } & : \text { kd_angsuran } \\
\text { Fungsi } & : \text { menginput data angsuran }
\end{array}
$$

Tabel 7 Angsuran

\begin{tabular}{lccc}
\hline Field Name & Type & Width & Keterangan \\
\hline kd_angsuran & Varchar & 20 & Primary key \\
tgl_pinjam & Date & & \\
tgl_angsur & Date & & \\
kd_pinjaman & Varchar & 20 & \\
no_anggota & Varchar & 20 & \\
nama & Varchar & 30 & \\
jml_pinjam & Varchar & 30 & \\
lama & Varchar & 5 & \\
tot_pinjaman & Varchar & 20 & \\
angsuran & Double & & \\
bulan_ke & Varchar & 3 & \\
tipe & Varchar & 30 & \\
angsuran_ke & Varchar & 3 \\
sisa & Varchar & 20 & \\
pokok & Varchar & 20 & \\
bunga & Varchar & 20 & \\
tot_angsur & Varchar & 20 & \\
\hline
\end{tabular}


8. Tabel Jurnal Umum

Nama Tabel : t_jurnal

Primary Key : Id_jurnal_umum

Fungsi : menginput data jurnal

Tabel 8 Jurnal Umum

\begin{tabular}{lccl}
\multicolumn{1}{c}{ Field Name } & Type & Width & Keterangan \\
\hline id_jurnal_umum & Int & 3 & Primary key \\
no_transaksi & Int & 3 & Foreign key \\
keterangan & Text & & \\
debet & Double & 20,0 & \\
kredit & Double & 20,0 & \\
\hline
\end{tabular}

9. Tabel Buku Besar

$\begin{array}{ll}\text { Nama Tabel } & : \text { t_bukubesar } \\ \text { Primary Key } & :- \\ \text { Fungsi } & : \text { menginput data buku besar }\end{array}$

Tabel 9 Buku Besar

\begin{tabular}{lccc}
\hline Field Name & Type & Width & Keterangan \\
\hline tanggal & Date & & \\
keterangan & Text & & \\
ref & Varchar & 10 & \\
nama_akun & Varchar & 50 & \\
normal & Varchar & 20 & \\
debet & Bigint & 20 & \\
kredit & Bigint & 20 & \\
\hline
\end{tabular}

10. Tabel Neraca Saldo

Nama Tabel : t_neracasaldo

Primary Key : kode_akun

Fungsi : menginput data neraca saldo

Tabel 10 Neraca Saldo

\begin{tabular}{lccc}
\hline Field Name & Type & Width & Keterangan \\
\hline kode_akun & Int & 10 & Primary Key \\
nama_akun & Varchar & 50 & \\
debet & Bigint & 20 & \\
kredit & Bigint & 20 & \\
\hline
\end{tabular}

\section{Tabel Pembagian SHU}

$\begin{array}{ll}\text { Nama Tabel } & : t \_s h u \\ \text { Primary Key } & :- \\ \text { Fungsi } & : \text { menginput data angsuran }\end{array}$

Tabel 11 Pembagian SHU

\begin{tabular}{lccc}
\hline Field Name & Type & Width & Keterangan \\
\hline Periode1 & Date & & \\
Periode2 & Date & & \\
Data & Varchar & 5 & \\
Totalshu & Varchar & 20 \\
Pengurus & Varchar & 20 \\
Pengurus1 & Varchar & 20 \\
Cadangan & Varchar & 20 \\
Cadangan1 & Varchar & 20 \\
Sosial & Varchar & 20 \\
Sosial1 & Varchar & 20 \\
Pendidikan & Varchar & 20 \\
Pendidikan1 & Varchar & 20 \\
Anggota & Varchar & 20 \\
Anggota1 & Varchar & 20 \\
PDK & Varchar & 20 \\
PDK1 & Varchar & 20 \\
\hline
\end{tabular}

\section{Implementasi dan Pengujian Sistem}

Implementasi Sistem

Tahap implementasi merupakan proses penerapan atau pelaksanaan sebagai tindakan yang dilakukan untuk menjalankan perangkat lunak atau aplikasi yang telah dirancang pada keadaan yang sebenarnya. Implementasi antarmuka (interface) dari aplikasi dilakukan berdasarkan rancangan yang telah dibuat. Implementasi yang ditampilkan merupakan hasil dari screenshot tampilan aplikasi yang digunakan sebagai bahan dan alat penelitian.

a) Antarmuka Form Login

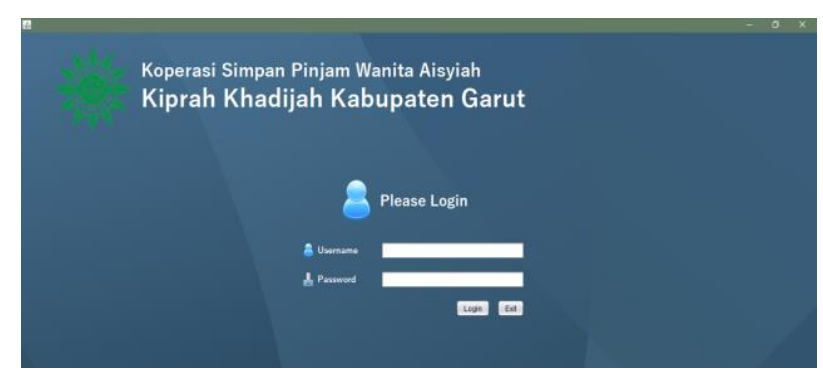

Gambar 10 Antarmuka Form Login

Form login merupakan tampilan pertama yang akan muncul saat aplikasi dijalankan. Dimana pada form login ini pengguna atau pengurus harus mengisi username dan password yang telah dimiliki oleh pengurus. 
b) Antarmuka Home

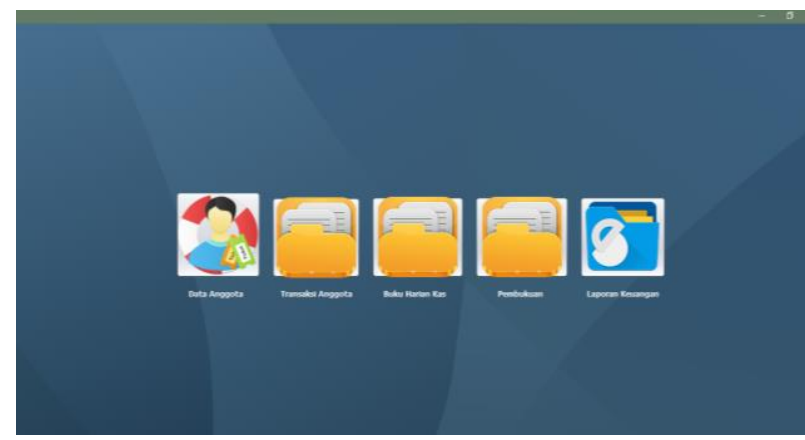

Gambar 11 Antarmuka Home

Pada tampilan home, terdapat menu utama dari aplikasi. Menu utama ini akan menampilkan beberapa menu seperti menu anggota, menu transaksi anggota, menu buku harian, dan menu laporan keuangan.

c) Antarmuka Menu Anggota

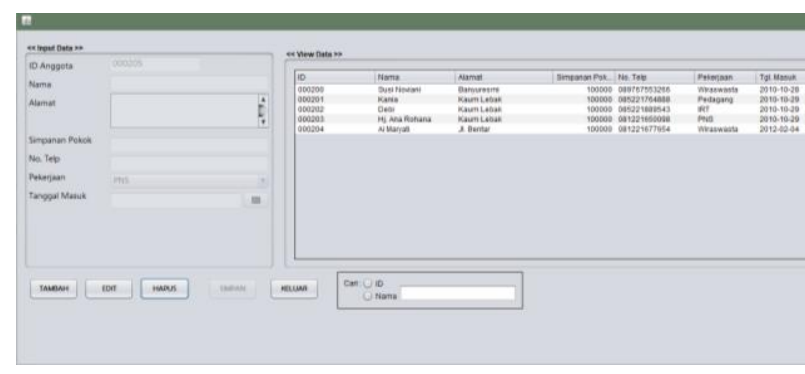

\section{Gambar 12 Antarmuka Menu Anggota}

Pada pada menu anggota, user dapat menambah anggota abru, mengedit data anggota, dan menghapus data anggota.

\section{d) Antarmuka Menu Transaksi Anggota}

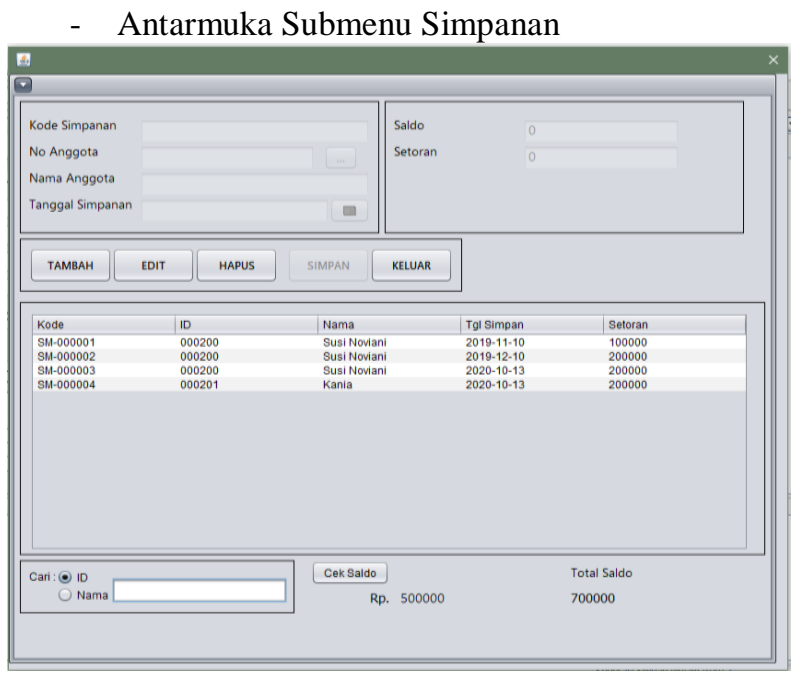

Gambar 13 Antarmuka Submenu Simpanan
Pada submenu simpanan, user dapat menginput data simpanan anggota dengan memilih no. anggota, memasukan tanggal transaksi serta menambah besar setoran. User juga dapat mengedit simpanan yang telah diinput dan menghapus simpanan jika ada kesalahan data pada saat penginputan.

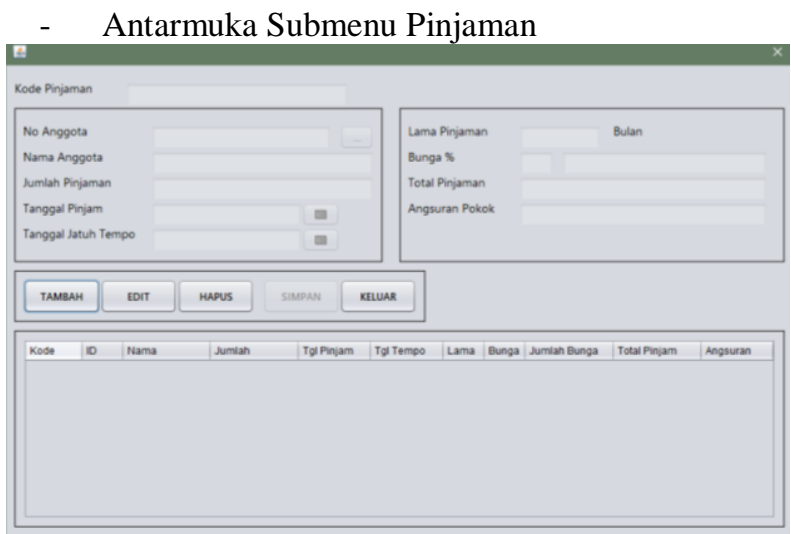

\section{Gambar 14 Antarmuka Submenu Pinjaman}

Pada submenu pinjaman, user dapat menginput data pinjaman anggota dengan memilih no. anggota, memasukan kode pinjaman, jumlah pinjaman, tanggal pinjam, tanggal jatuh tempo, lama pinjaman, besar bunga, total pinjaman serta angsuran pokok. User juga dapat mengedit pinjaman yang telah diinput dan menghapus pinjaman jika ada kesalahan data pada saat penginputan.

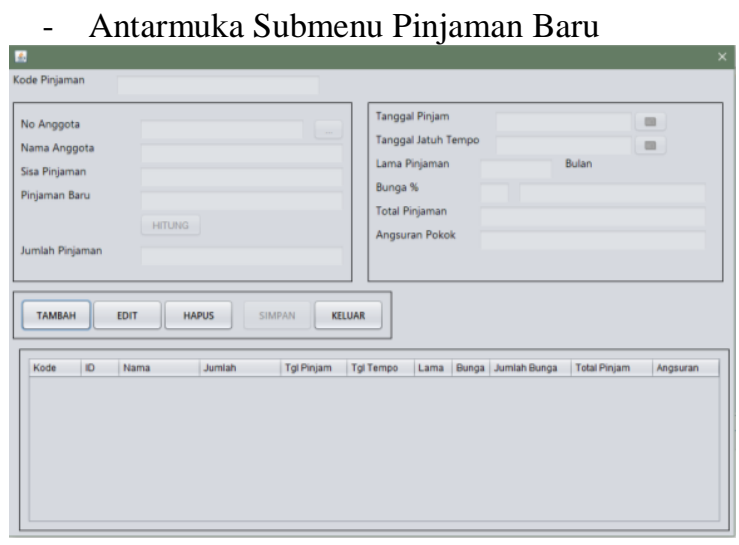

\section{Gambar 15 Antarmuka Submenu Pinjaman} Baru

Pada submenu pinjaman baru, user dapat menginput data pinjaman baru anggota dengan memilih no. anggota, memasukan kode pinjaman, jumlah pinjaman, tanggal pinjam, tanggal jatuh tempo, lama pinjaman, besar bunga, total pinjaman serta angsuran pokok . User juga dapat mengedit 
pinjaman baru yang telah diinput dan menghapus pinjaman baru jika ada kesalahan data pada saat penginputan.

- Antarmuka Submenu Angsuran

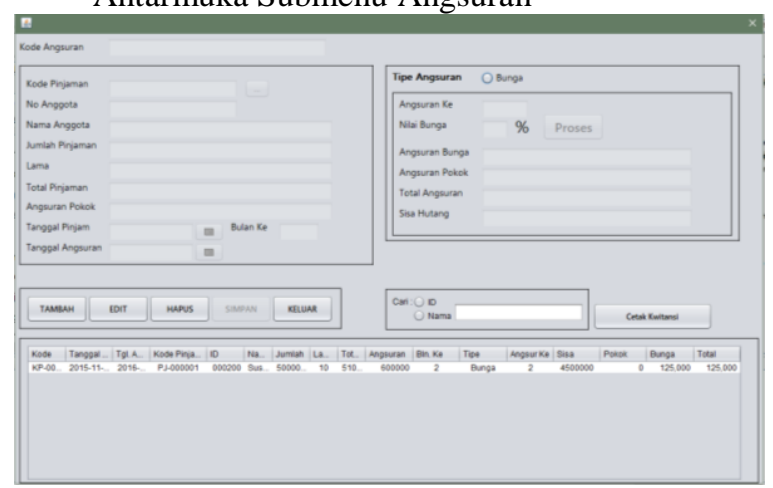

\section{Gambar 16 Antarmuka Submenu Angsuran}

Pada submenu angsuran, user dapat menginput data angsuran anggota dengan memilih no. anggota, memasukan kode pinjaman dan kode angsuran, jumlah pinjaman, tanggal pinjam dan tanggal angsuran, hingga sisa hutang. User juga dapat mengedit data angsuran yang telah diinput dan menghapus data angsuran jika ada kesalahan data pada saat penginputan.

\section{- Antarmuka Submenu Pembagian SHU}

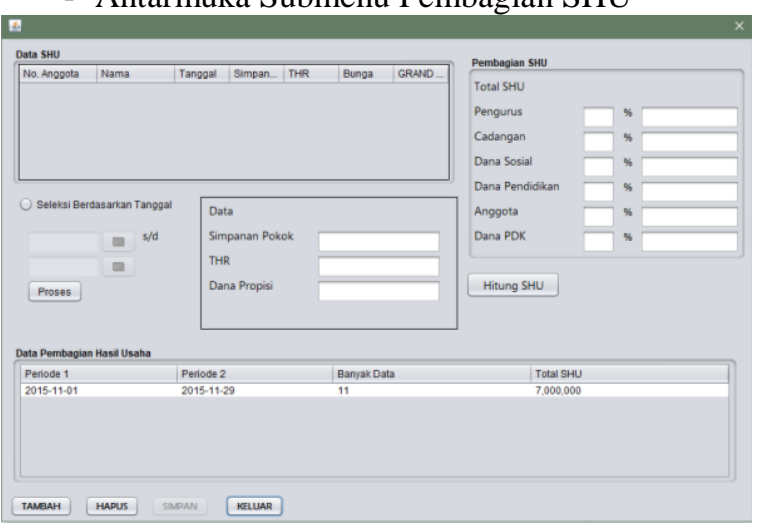

\section{Gambar 17 Antarmuka Submenu Pembagian} SHU

Pada submenu pembagian SHU, user dapat menginput data besaran SHU yang berlaku dan otomatis terhitung. e) Antarmuka Menu Laporan Keuangan

1) Antarmuka Laporan Neraca

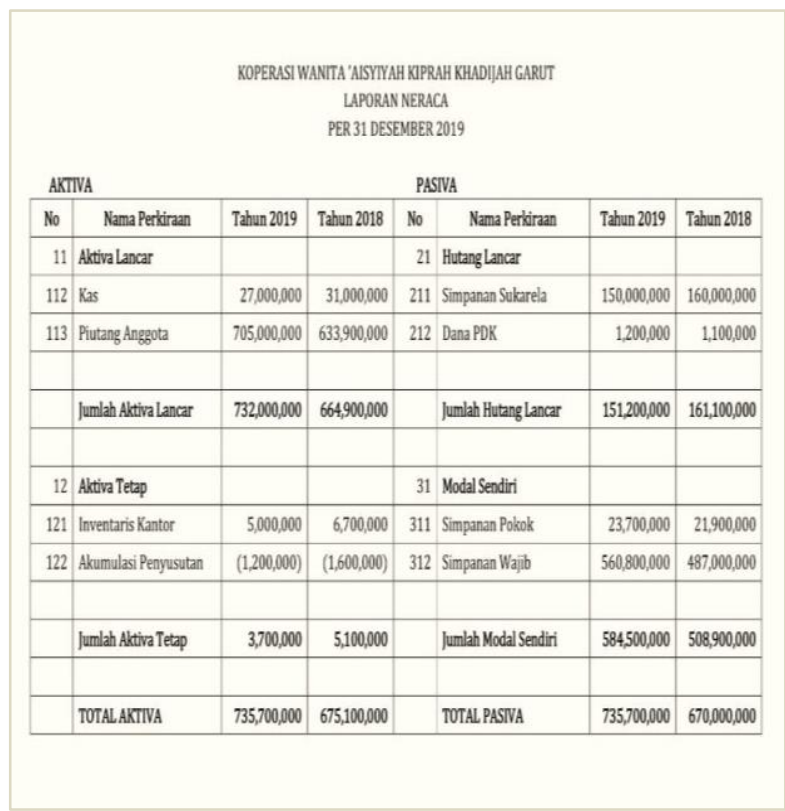

\section{Gambar 18 Antarmuka Laporan Neraca}

2) Antarmuka Perhitungan Sisa Hasil Usaha

\begin{tabular}{|c|c|c|}
\hline \multicolumn{3}{|c|}{$\begin{array}{c}\text { KOPERASI WANITA 'AISYIYAH KIPRAH KHADIJAH GARUT } \\
\text { LAPORAN PERHITUNGAN SISA HASIL USAHA } \\
\text { PER } 31 \text { DESEMBER } 2019\end{array}$} \\
\hline & 31 Des 2019 & 31 Des 2018 \\
\hline \multicolumn{3}{|l|}{ Pendapatan } \\
\hline Pendapatan Jasa & $72,000,000$ & $70,000,000$ \\
\hline Jumlah & $72,000,000$ & $70,000,000$ \\
\hline \multicolumn{3}{|l|}{ Biaya-biaya } \\
\hline Biaya Listrik & 500,000 & 400,000 \\
\hline Biaya Penyusutan & $1,000,000$ & 900,000 \\
\hline Jumlah Biaya & $1,500,000$ & $1,300,000$ \\
\hline SHU & $70,500,000$ & $68,700,000$ \\
\hline
\end{tabular}

\section{Gambar 19 Antarmuka Laporan Perhitungan Sisa Hasil Usaha}


3) Antarmuka Laporan Perubahan Modal

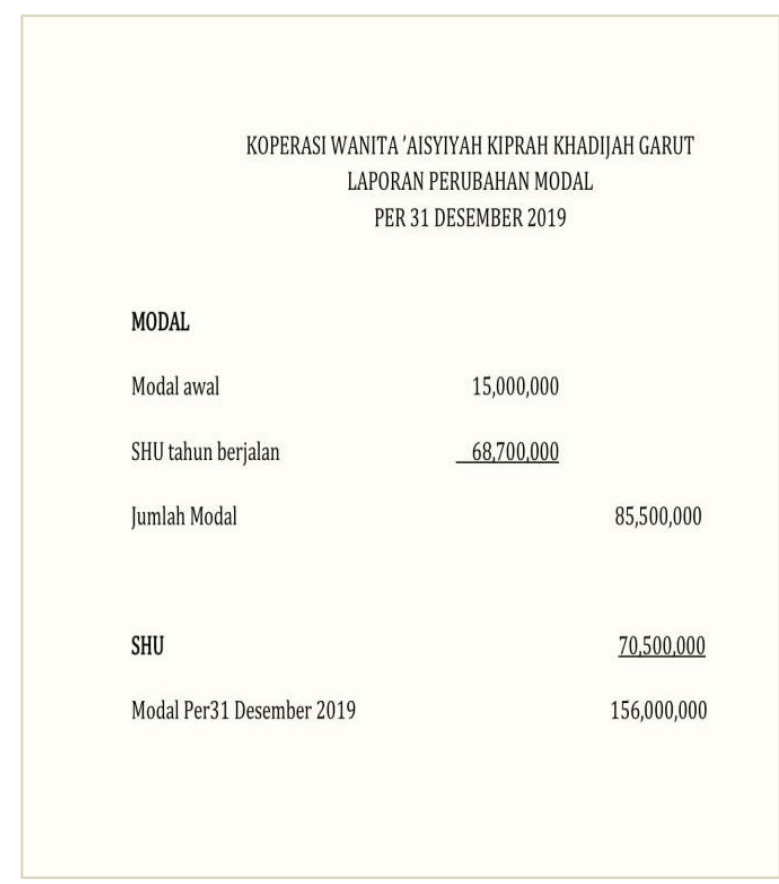

\section{Gambar 20 Antarmuka Laporan Perubahan} Modal

4) Antarmuka Laporan Arus Kas

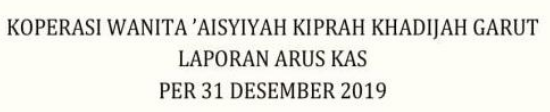

SHU

Arus kas dari aktivitas operasi :

Kenaikan piutang anggota

Kas bersih dari aktivitas operasi

Pembelian perlengkapan

Kas bersih dari aktivitas investasi

Arus kas dari aktivitas pembiayaan :

Simpanan Pokok

Simpanan Wajib

Kas bersih dari aktivitas pembiayaan

Kas awal periode 1 Desember 2019

Kas akhir periode 31 Desember 2019
Arus kas dari aktivitas investasi :
$70,500,000$

$(108,000,000)$

$(37,500,00)$

$(2,000,000)$

$(2,000,000)$

$60,000,000$

$\underline{100,000,000}$

$160,000,000$

$120,500,000$

\section{Gambar 21 Antarmuka Laporan Arus Kas}

\section{SIMPULAN DAN SARAN}

Sistem Informasi Akuntansi yang berjalan masih dilakukan secara manual menggunakan microsoft excel, dimana keamanan penyimpanan data belum dapat dikatakan baik karena dapat diakses oleh pihak luar, selain itu data yang disimpan dapat hilang jika terjadi kesalahan dalam penggunan atau kerusakan pada komputer karena data tidak terbackup. Aplikasi yang diusulkan penulis berbasis aplikasi desktop yang bertujuan agar proses pencatatan pelaporan keungan berjalan efektif dan efisien telah dirancang sesuai dengan kebutuhan Koperasi.

Aplikasi sistem informasi akuntansi ini masih jauh dari kata sempurna. Untuk itu dibutuhkan pengembangan aplikasi baik dari sisi manfaat maupun kinerja dari aplikasi itu sendiri. Berikut beberapa saran bagi koperasi dan penelitian selanjutnya untuk pengembangan aplikasi Diharapkan Koperasi dapat menggunakan aplikasi yang diusulkan agar proses pencatatan keuangan dapat berjalan secara efektif dan efisien. Serta diharapkan penelitian ini dijadikan bahan referensi untuk pengembangan sistem yang lebih sempurna.

\section{DAFTAR PUSTAKA}

Abdillah, J. (2017). Perancangan Sistem Informasi Akuntansi Simpanan Mudharabah dan Pinjaman Qardhul Hasan Berbasis Web Pada Koperasi Syariah. Jurnal Riset Akuntansi dan Keuangan, 5(2), 1441-1464.

Adipati, N. M., \& Nur'ainy, R. N. (2019). Perancangan Sistem Informasi Akuntansi Simpanan Pada Koperasi Syariah Bina Usaha Muhajirin (Bumi). Jurnal Riset Akuntansi dan Keuangan, 6(3), 319-332.

Akuntansi Online. (2016). Perkembangan Terkini Teknologi Informasi Akuntansi. Diakses 25 Maret 2020, dari https://www.akuntansionline.id/perkembanganterkini-teknologi-informasi-akuntansi/.

Al-Bahra Bin Ladjamudin. (2005). Analisis dan Desain Sistem Informasi. Yogyakarta: Graha Ilmu.

Aladinika, S. (2019). Membangun Sistem Rekomendasi Seleksi Pemberian Dana Prestasi Menggunakan Metode Weighted Product (Studi Kasus PT Kode Teknologi Indonesia (Tlab) Yogyakarta) (Doctoral dissertation, University of Technology Yogyakarta).

Anisyah, (2000) Analisa dan Desain Sistem Informasi. Yogyakarta: PT. Andi Offset. 
Arhami, Muhammad. (2010). Data Flow Diagram (DFD) Dan Kamus Data. Politeknik Negeri Lhokseumawe : Program Studi Teknik Informatika Jurusan Teknik Elektro.

Essiitech Sosmed. (2019). Kelebihan dan Kekurangan Program Desktop dan Web Based. Diakses 8 April 2020, dari http://essiitech.com/portfolio/kelebihan-dankekurangan-program-desktop-dan-web-based.

Hilman. (2016). Perbedaan Aplikasi Berbasis Web, Aplikasi Berbasis Desktop, dan Aplikasi Berbasis Mobile. Diakses 8 April 2020, dari https://www.plimbi.com/article/166177/aplikas i-berbasis-web--desktop-dan-mobile.

Ikatan Akuntan Indonesia (IAI). (2009). Standar Akuntansi Keuangan Entitas Tanpa Akuntabilitas publik (SAK ETAP). Jakarta: Dewan Standar Akuntansi Keuangan Ikatan Akuntan Indonesia

Ikatan Akuntan Indonesia. (2015). Pernyataan Standar Akuntansi Keuangan. Jakarta: Ikatan Akuntan Indonesia.

Indrayati. (2015). Sistem Informasi Akuntansi (Teori Dan Konsep Desain SIA) Yogyakarta: Aditya Media Publishing.

Jogiyanto, HM. (2001). Analisis Perancangan Sistem Informasi. Yogyakarta: PT. Andi Offset.

Konixbam. (2009). Aplikasi Desktop Menggunakan VB. Net. Surabaya.

Kusrini. (2007). Konsep dan Aplikasi Sistem Pendukung Keputusan. Yogyakarta : Penerbit Andi.

Kusuma, R. D., Adipranata, R., \& Noertjahyana, A. (2015). Perancangan Pembuatan Sistem Informasi Akuntansi Pada PT X. Jurnal Infra, 3(1), 285-289.

Lestari, D. P. (2017). Perancangan Sistem Informasi Akuntansi penggajian dengan mengunakan Microsoft Visual Basic 2008 dan database MySQL. @ is The Best: Accounting Information Systems and Information Technology Business Enterprise, 2(2), 149167.

Mallu, S. (2015). Sistem pendukung keputusan penentuan karyawan kontrak menjadi karyawan tetap menggunakan metode topsis. Jurnal Ilmiah Teknologi Infomasi Terapan, 1(2).
Menteri Koperasi dan UKM RI. (2015). Peraturan Menteri Koperasi dan Usaha Kecil dan Menengah Republik Indonesia Nomor 13/Per/M.KUKM/IX/2015 tentang Pedoman Akuntansi Usaha Simpan Pinjam Oleh Koperasi.

Menteri Koperasi dan UKM RI. (2015). Peraturan Menteri Koperasi dan Usaha Kecil dan Menengah Republik Indonesia Nomor 15/Per/M.KUKM/IX/2015 tentang Usaha Simpan Pinjam Oleh Koperasi.

Mujilan. (2015). Sistem Informasi Akuntansi : Teori dan Wawasan di Dunia Elektronis. Madiun : Program Studi Akuntansi Universitas Widya Mandala Madiun.

Mukhtar. (2013). Metode Penelitian Deskriftif Kualitatif. Jakarta : GP Press Group.

Mulyanto, Agus. (2009). Sistem Informasi Konsep dan Aplikasi. Yogyakarta : Pustaka Pelajar.

Munawir, S. (2010). Analisis laporan Keuangan Edisi keempat. Cetakan Kelima Belas. Yogyakarta: Liberty

Nayaka, A. B. S., \& Suardikha, I. M. S (2015). Kepuasan Kerja dan Integritas sebagai Pemoderasi Pengaruh Penerapan Sistem Informasi Akuntansi pada Kinerja Karyawan. E-Jurnal Akuntansi, 454-483.

Ninik Widiyanti \& Sunindhia. (2009). Koperasi dan Perekonomian Indonesia. Jakarta: Rineka Cipta

Pemerintah Indonesia. Undang-Undang Nomor 25 Tahun 1992 tentang Perkoperasian. Lembaran Negara RI Tahun 1992 No. 116. Jakarta : Sekretariat Negara.

Rouf, A. (2012). Pengujian perangkat lunak dengan menggunakan metode white box dan black box. HIMSYATECH, 8(1).

Rudianto. (2010). Akuntansi Koperasi Edisi Kedua. Jakarta. Erlangga.

Sasmito, G. W. (2017). Penerapan Metode Waterfall Pada Desain Sistem Informasi Geografis Industri Kabupaten Tegal. Jurnal Informatika: Jurnal Pengembangan IT, 2(1), 612.

Singgih Santoso. (2006). Menggunakan SPSS untuk Statistik Non Parametrik. Jakarta: PT. Elex Media Komputindo.

Sugiyono. (2013). Metode Penelitian Kuantitatif, Kualitatif dan R\&D. Bandung: Alfabeta.CV 
78 Coopetition, Vol XII, Nomor 1, Maret 2021, 65 - 78

(E-ISSN : 2615-4978, P-ISSN : 2086-4620)

Tanjaya, P., Rostianingsih, S., \& Hatane, S. E. (2016). Perancangan dan Pembuatan Aplikasi Sistem Informasi Akuntansi Atas Siklus Pengeluaran dan Pendapatan untuk UD X. Jurnal Infra, 4(1), 286-291.

Wardana, W. B., Abukosim, A., \& Hakiki, A. (2018). Analisis Dan Perancangan Sistem Informasi Akuntansi Unit Simpan Pinjam Koperasi Sumber Rejeki (Doctoral dissertation, Sriwijaya University).

Widjajanto, Nugroho. (2001). Sistem Informasi Akuntansi. Jakarta: Erlangga

Yuhendra, Y. (2014). Perancangan Sistem Inventory Spare Parts Mobil Pada Cv. Auto Parts Toyota Berbasis Aplikasi Java. Jurnal TeknoIf, 1(2). 